\title{
LEI E VIOLÊNCIA OU A LEGITIMAÇÃO POLÍTICA EM MAQUIAVEL
}

RESUMO: Uma das mais famosas e inovadoras teses de Maquiavel é a afirmação de que as boas leis nascem dos conflitos sociais, segundo o exemplo romano das oposições entre plebe e nobres. Os conflitos são capazes de produzir ordem por conter a força constritiva própria da necessidade, que impede a ambição de reinar. Contudo, a lei não neutraliza o conflito, mas apenas lhe dá uma ordenação. A lei está, pois, exposta à história, à contínua mudança, o que significa dizer que é potencialmente corruptível. Por causa desta possibilidade, Maquiavel afirma que um Estado somente mantém sua autoridade por meio de um retorno contínuo ao momento da origem, isto é, à revivência da experiência do "medo", do "terror" e da "punição" do acontecimento originário da fundação. Assim, na origem da lei está a violência, cuja função é proporcionar a legitimação de seu exercício pelo aparato estatal como única forma de preservar da ruína a vida política.

PALAVRAS-CHAVE: Maquiavel. Lei. Violência. Conflito. Política. Estado.

Maquiavel, contrapondo-se à opinião comum de seus contemporâneos, destitui o exemplo espartano de sua grandeza. No lugar da exemplaridade de um sábio legislador que dota a cidade desde as origens de uma constituição estável e duradoura, destaca o modelo romano, cuja constituição se estabeleceu no curso dos acontecimentos, aperfeiçoando-se ao longo da história. Em vez da sabedoria legislativa de Licurgo, Maquiavel prefere a violência de Rômulo, que fundou Roma sobre a morte de seu irmão. Essa relação entre lei e violência é circunstancial ou pertence à estrutura mesma das instituições políticas? Se o diritto cammino da instituição da lei não passa pela doação desta, pela mediação de uma personalidade singular, mas é um produto histórico, então precisa ser relacionada com o conflito

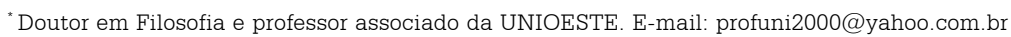


inerente às sociedades. Isso obriga a explicar a função do conflito, na formulação da lei. Considerando a circularidade de lei e história, é preciso contar com a potencial corruptibilidade do aparato institucional: qual a relação entre lei, conflito e violência, no processo de contenção da corrupção?

Nosso propósito será demonstrar a originalidade da posição de Maquiavel, ao vincular a lei aos distintos modos de dar vazão aos conflitos que dilaceram a sociedade. É preciso, porém, afastar essa ideia de uma leitura mecanicista segundo a qual a concórdia da lei seria necessária e unilateralmente resultante da discórdia. Procuraremos evidenciar, pelo contrário, que a violência que funda o Estado é a mesma a qual constitui a lei, pois tanto o Estado quanto a lei visam a abolir a violência originária existente "antes" ou "à margem" de todo ordenamento estatal e legal. Quando o conflito se degrada, isto é, quando passa a se reger pela ambição (privada) de cargos e riquezas e não pela necessidade, a corrupção, ou seja, a destruição do público, se instala. Nessa situação, não há outro modo de eliminar a corrupção, senão refundando o político em suas origens e princípios. Este é o caminho defendido por Maquiavel: um Estado somente mantém sua autoridade por meio de um retorno contínuo ao momento da origem. Significa dizer: àquele momento da violência de Rômulo, e essa volta repõe a lei na indeterminação originária que, por sua vez, a recoloca em movimento.

\section{Conflito de humores e liberdade}

O ponto de partida para o entendimento da questão é a enunciação da tese da oposição irredutível dos humores de grandes e povo, presente nas três obras políticas principais ${ }^{1}$. A partir da constatação do enfrentamento permanente de dois desejos (dominar/não ser dominado) que não podem ser saciados simultaneamente, Maquiavel extrai a conclusão, escandalosa para

\footnotetext{
${ }^{1}$ Em O Príncipe IX: “[...] porque em toda cidade existem estes dois humores diversos que nascem disso: o povo deseja não ser comandado nem oprimido pelos grandes, e os grandes desejam comandar e oprimir o povo". Nos Discursos I,4: "E sem dúvida, se considerarmos o objetivo dos nobres e dos plebeus [nobili e degli ignobili], veremos naqueles grande desejo de dominar e nestes somente o desejo de não ser dominados e, por conseguinte, maior vontade de viver livres [...]". Finalmente, na História de Florença III,1: "As graves e naturais inimizades que há entre os homens do povo e os nobres, causadas pela vontade que estes têm de comandar e aqueles de não obedecer [...]".

${ }^{2} \mathrm{O}$ caráter escandaloso que a tese maquiaveliana da vitalidade das dissensões representava para um pensamento político obnubilado pela concórdia pode ser medido pelo comentário crítico de um contemporâneo (e amigo pessoal) de Maquiavel: "Louvar as dissensões é como louvar a enfermidade de um enfermo pela qualidade do remédio que lhe foi aplicado." (GUICCIARDINI,1933, p. 10)

${ }^{3}$ Quando Maquiavel fala de "liberdade", pode referir-se a duas modalidades distintas, uma externa e outra interna, mas nem uma nem outra é uma qualidade própria ao indivíduo: pode significar a autonomia e a independência de um Estado em relação à outra potência; ou pode referir-se a
} 
seus contemporâneos ${ }^{2}$, de que a liberdade ${ }^{3}$, isto é, a vida política (vivere politico), nasce precisamente dessa desunião.

Segundo o modelo do conflito político, ao desejo desmesurado dos grandes pela apropriação/dominação absoluta, opõe-se um desejo não menos desmesurado e absoluto do povo de não sê-lo, de não ser dominado nem dominar ${ }^{4}$. Ao caracterizar o desejo dos grandes como um desejo de comandar e o do povo como de viver em liberdade, Maquiavel deixa claro que aquilo que funda a relação política não se confunde nem com a regulação do desejo de poder (dos grandes), nem com a regulação do desejo de liberdade (do povo). É, pelo contrário, a diferença definitiva dos humores que, em linguagem mais atual, podemos denominar "desejos".

A centralidade do conflito não está limitada, porém, à oposição interna à coletividade política dos "humores" de grandes e povo. Este é o ponto, talvez, mais visível, mas seria um equívoco reduzir tudo a esse confronto. Com efeito, além da oposição dos "partidos" no interior do Estado, o conflito das paixões está igualmente na base da rivalidade entre os indivíduos singulares, assim como da guerra entre os Estados. Em relação à centralidade do conflito, é preciso ter presentes alguns pontos aos quais é preciso chamar a atenção. Por um lado, o conflito permanece irresolvido, o que significa dizer que, em vez de a política ser a neutralização dele, o máximo que ela consegue é ser sua regulação. Por outro lado, uma vez que o conflito não se esgota intramuros, mas se manifesta também na expansão dos Estados, há uma ligação íntima entre política e guerra. Por fim, do conflito (em quaisquer de suas três formas - como rivalidade de paixões entre singulares; como oposição dos humores de partidos e como guerra) não é possível determinar a priori sua natureza - construtiva ou destrutiva -, mas apenas a partir das circunstâncias concretas nas quais se manifesta.

determinada ordem política, na qual os cidadãos têm participação ativa no governo. Concordamos nisso com Gennaro Sasso, para quem o sujeito e protagonista da liberdade, para Maquiavel, é sobretudo o Estado: "Aquilo que enfim conta, para Maquiavel, não é que os cidadãos sejam 'livres', mas que o Estado seja efetivamente 'senhor' de seu conteúdo, político e social e, para isso, dure." (SASSO, 1980, p. 470). Uma interpretação diferente desta, por exemplo, é oferecida por Quentin Skinner (1998), que coloca em primeiro plano a liberdade individual. Sustenta que a liberdade teorizada por Maquiavel pode ser considerada uma forma de "liberdade negativa", unida firmemente à liberdade individual e à liberdade coletiva. O curso de nossa exposição deixará claro que a posição de Sasso é mais pertinente.

${ }^{4}$ A passagem abriu espaço para o conflito das interpretações sobre o papel do povo na constituição da vida política. Bignotto (1991, p. 106-107), contra aqueles que, como G. Sasso e F. Chabod, atribuem ao povo apenas um papel passivo na política, sustenta: "Se o desejo popular, que é essencialmente desejo de liberdade, fosse totalmente passivo, não estaria ele desde o início condenado ao fracasso? Nestas condições, o saber da política, que é sempre um saber operativo, não seria unicamente aquele da nobreza, que em sua objetividade se confronta sempre com o desejo cego de liberdade? A conclusão não poderia ser mais estranha para um autor que conduz sua análise sob o signo da potência romana, tomada não como um modelo, mas como o produto de uma ação contínua na 'polis'". A sequência de nossa argumentação se alinha à posição de Bignotto. 
Vamos procurar esclarecer melhor essas afirmações. A leitura do final do terceiro e, em seguida, de todo o capítulo quarto do primeiro livro dos Discursos, clarifica a novidade da posição de Maquiavel: ordem não é o oposto de desordem, de forma tal que uma poderia existir somente se a outra não se fizesse presente; ao contrário disso, o florentino institui entre ambas uma relação intrínseca, "orgânica", poderíamos dizer, de tal maneira que uma pressupõe a outra. Para compreender adequadamente isso, precisamos ir aos textos.

A opinião comum reinante entre os contemporâneos de Maquiavel era a de que "Roma foi uma república tumultuária e tão cheia de confusão que, se a boa fortuna e a virtù militar não tivessem suprido seus defeitos, ela teria sido inferior a qualquer outra república" (Discursos I,4). Maquiavel inverte essa posição: reconhece que a grandeza de Roma não teria sido possível sem uma coesão interna, como pregava o republicanismo emergido do humanismo cívico, mas defende que essa coesão resulta do conflito e da expansão deste para fora do Estado romano e não da neutralização dele (como queria o humanismo cívico)

O conflito não é, para Maquiavel, equivalente ao caos ou à desordem, mas está na base da ordem. Contudo, a ordem é apenas uma possibilidade e não uma necessidade, de sorte que o conflito contém uma potencialidade ambivalente de produção de ordem e de desordem. Essa ambivalência pode ser mais bem compreendida pelo confronto de dois capítulos do primeiro livro dos Discursos: 4 e 37.

No capítulo 4:

Toda cidade deve ter os seus modos para permitir que o povo desafogue sua ambição, sobretudo as cidades que queiram valerse do povo nas coisas importantes: a cidade de Roma, por exemplo, tinha este modo quando o povo queria obter uma lei, ou fazia alguma das coisas acima citadas ou se negava a arrolar seu nome para ir à guerra, de tal modo que, para aplacá-lo, era preciso satisfazê-lo em alguma coisa. E os desejos dos povos livres raras vezes são perniciosos à liberdade, visto que nascem ou de serem oprimidos ou da suspeita de que virão a sê-lo. (grifos nossos).

No capítulo 37

Porque todas as vezes que os homens são tolhidos de combater por necessidade, combatem por ambição; esta é tão poderosa no peito humano que nunca, seja qual for a posição atingida, os abandona. A razão disso é que a natureza criou os homens de tal modo que eles podem desejar qualquer coisa, mas não podem 


\begin{abstract}
conseguir qualquer coisa; e, assim, sendo sempre maior o desejo que o poder de adquirir, surgem o descontentamento por aquilo que se possui e a pouca satisfação com isso. Daí nasce a variação da fortuna deles: porque, em parte os homens desejam mais, em parte temem perder o adquirido, chegam à inimizade e à guerra, da qual decorre a ruína de uma província e a exaltação de outra. Tudo isso eu disse porque à plebe romana não bastou obter garantias contra os nobres, pela criação dos tribunos, desejo ao qual foi forçada por necessidade; pois ela, tão logo obteve isso, começou a lutar por ambição e a querer dividir cargos e patrimônio com a nobreza como as coisas mais estimadas pelos homens. Daí surgiu a doença que gerou o conflito da lei agrária, que acabou por ser a causa da destruição da república. (grifos nossos).
\end{abstract}

Primeiramente, os fragmentos permitem perceber que ambição e desejo são tendências inerentes a todo ser humano. Em segundo lugar, que o valor dessas tendências não é determinado abstratamente, mas segundo as circunstâncias concretas nas quais se expressam. Assim, no capítulo 4, a ambição do povo é a força "que fez livre e poderosa" a república romana: na medida em que os governantes souberam dar "saída" (sfogo) adequada à ambição e aos desejos do povo, fizeram dessas tendências forças propulsoras para a construção da grandeza e da liberdade da república romana.

No capítulo 37, ao invés disso, ambição e desejos são fatores de dissolução da liberdade republicana. As tendências, consideradas desde o ponto de vista antropológico, são as mesmas. O que faz, então, a diferença delas em relação ao outro capítulo? A primeira frase da passagem citada o explica: os homens deixaram de combater por necessidade para combater por ambição. Expliquemos melhor: enquanto grandes e povo são obrigados a lutar para garantir sua existência (o povo, a liberdade e os grandes, a dominação), a ambição atua virtuosamente, porque é contida pela força contrária que a impede de expandir-se ao infinito. Quando, porém, o povo se vê liberado da necessidade de lutar pela afirmação de sua liberdade, experimenta a imensidão do próprio desejo, passa a querer o domínio como os grandes e não com eles. Em outras palavras, quando a ambição, ou seja, a capacidade natural "de desejar qualquer coisa", não é limitada por uma ambição contrária que a impeça "de querer tudo", a necessidade (quer dizer, os mecanismos constritivos à satisfação dos desejos) desaparece e o caos e a desordem se instalam.

Evidencia-se, pois, que desejo e ambição não têm um "valor em si" positivo ou negativo -, mas são determinados pelas circunstâncias concretas nas quais se manifestam. Essas circunstâncias, como podemos notar, são as 
relações de poder entre grandes e povo: no momento em que cada um se vê obrigado a lutar para afirmar seu desejo (isto é, vê sua ambição ao infinito contida pelo desejo contrário do outro), emerge do confronto a ordem favorável à liberdade de todos; quando, porém, qualquer uma das partes se percebe liberada dessa necessidade (isto é, quando a ambição pode expandir-se sem sofrer limitação), a relação de poder se desequilibra e arrasta a coletividade ao caos e à desordem. Em suma, Maquiavel não pensa a ordem política como neutralização do conflito, mas como seu parcial e transitório ordenamento.

\section{Lei e conflito de humores}

O conflito é, pois, de tal modo constitutivo à vida política que podemos dizer que é aquilo que a faz existir. Só é possível existir vida política onde o conflito tem estruturas institucionais para dar-lhe vazão ${ }^{5}$. Uma vez que o aparato institucional se inscreve no conflito a ponto de ser impossível subtrairse a ele, nos deparamos com o problema de explicar como se produz essa relação entre ambos (lei e conflito). A resposta parte da constatação de que "[...] os homens agem por necessidade ou por escolha e se vê que existe maior virtù onde a escolha tem menos autoridade" (Discursos I,1). Por causa disso, jamais os Estados "[...] se ordenarão sem perigo; porque a multidão nunca anui a uma lei nova que tenha em vista uma nova ordem na Cidade a menos que lhes seja mostrado, por alguma necessidade, que é preciso fazêlo" (Discursos I,2 - grifos nossos). Todo o problema está posto aqui: se a multidão não se dobra à lei espontaneamente, mas apenas forçada pela necessidade, o que poderia ter esse efeito constritor de levar os homens a agir "por necessidade" e não "por escolha"? Esta é, precisamente, a função que Maquiavel confere ao conflito: ele não somente contém essa força constritiva própria à necessidade (porque deixa patentes os interesses contraditórios e inconciliáveis dos grupos, bem como a urgência de dar solução satisfatória a eles), mas impõe uma decisão na discórdia (quer dizer, sem que esta seja neutralizada).

Não podemos, portanto, concluir a partir desse raciocínio que haveria um nascimento espontâneo das instituições, as quais extrairiam de uma vez para sempre da ordem da lei a solução automática da desordem do conflito. Pelo contrário, por um lado, os tumultos somente são férteis por causa do perigo que representam, pois apenas dessa maneira são capazes

\footnotetext{
${ }^{5}$ Lefort (1999, p. 166) chega a enfatizar que, quando a concórdia é obtida "ao custo de instituições que mascaram a divisão daqueles desejos, que impedem o povo de satisfazer seu 'humor', então a concórdia descortina os sinais de uma sociedade mutilada". O que Lefort alerta é, portanto, que a estabilidade política não é um valor em si. O sinal de vitalidade de uma coletividade política é determinado por sua ligação com a liberdade e, desta, temos evidências quando as diferenças podem expressar-se institucionalmente.
} 
de fazer os homens agir "por necessidade". Por outro lado, e em consequência disso, é sempre possível que o conflito abra as portas à guerra civil, que leva o Estado à ruína, em vez de criar leis e instituições propiciadoras de um vivere libero. Para Maquiavel, os conflitos permanecem sadios e não se tornam patológicos, isto é, as desunioni não se transformam em discordie civili, sob duas condições: primeiro, que "[...] se mantenham sem as seitas e os partidários" (História de Florença VII,1); segundo, que não "[...] comecem a lutar por ambição" nem tenham por objeto a "riqueza", mas as "honras" (Discursos I,37). Em outras palavras, que a luta política não assuma uma dimensão personalista nem tome um caráter privado.

Maquiavel faz uma crítica recorrente às divisões que dão lugar aos partigiani e às sette ou fazioni. No começo dos Discursos (I,7), por exemplo, ao defender o instituto da "acusação pública", recorda o exemplo de Coriolano, impedido pelos tribunos de ser morto pela turba enraivecida, para concluir o que acontece quando os cidadãos recorrem às vie privatte: "[...] o medo busca defesas; para a defesa arranjam-se partidários; dos partidários nascem as facções nas cidades; das facções, a sua ruína". No capítulo 37, mostra que em Roma "[...] se recorreu aos remédios privados" quando a plebe passou "[...] a querer dividir cargos e patrimônio com a nobreza" e a consequência final desse litígio foi "[...] a destruição da república". Em suma, quando os conflitos assumem um caráter de disputa privada, seja para satisfazer os interesses fora da regulação legal, seja para utilizar-se dos cargos públicos em benefício próprio, eles deixam de ser fonte da liberdade para tornar-se instrumentos da ruína da vida política.

As dissensões não são, por conseguinte, necessariamente boas. Como se depreende do que dissemos acima, a relação entre conflito e lei pressupõe um ethos favorável ao vivere libero para que produza bons efeitos. Nas palavras de Maquiavel, tratando de Roma: "[...] não se pode ter razão para chamar de não ordenada uma república dessas, onde há tantos exemplos de virtù; porque os bons exemplos nascem da boa educação; a boa educação, das boas leis e as boas leis, dos tumultos que muitos condenam sem ponderar." (Discursos I,4).

Berns (2000, p. 116-118) chama a atenção para a importância da circularidade entre tumultos, leis e exemplos virtuosos, expressa na passagem citada, porque, com essa posição, segundo ele, Maquiavel consegue resolver o dilema com o qual o confrontavam os críticos dos tumultos romanos na Florença de então ${ }^{6}$. Com efeito, se existisse uma pura desordem (ou seja, caos) antes da ordem instaurada pela lei, esta seria apenas

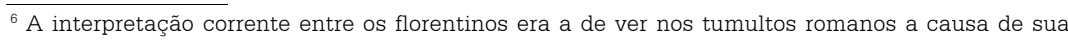
ruína. Dessa maneira, a tese maquiaveliana, que via neles o fundamento da liberdade, só poderia ser motivo de escândalo
} 
contingente e, nesse caso, a grandeza de Roma deveria ser atribuída unicamente à fortuna, tal como defendiam seus conterrâneos. Maquiavel descarta, porém, decididamente esse argumento: "Não posso negar que a fortuna e a milícia foram causas do império romano, mas também me parece que aqueles que dizem tais coisas não se apercebem de que onde é boa a milícia convém que seja boa a ordem, e raras vezes não deixa de haver também boa fortuna." (Discursos I,4). Em outras palavras, ironicamente, Maquiavel sustenta que a "boa fortuna" não é puramente casual, mas é resultado das boas instituições, notadamente de uma força militar poderosa. Com boas instituições, é possível "produzir" uma boa fortuna...

Contudo, essa conclusão não dispensa Maquiavel de pensar a relação da desordem (os conflitos e tumultos), por ele elogiada, com a ordem (a estrutura legal e institucional). Assim, se, por um lado, o êxito de Roma não pode ser concedido à fortuna e se, por outro, não tem como remeter a origem da ordem a uma instância exterior (a um primeiro legislador virtuoso), como o problema se resolve?

A força do argumento maquiaveliano está na circularidade, sustenta Berns: os tumultos romanos não podem ser condenados como pura desordem, porque não prejudicam a virtude. Os exemplos romanos provam que a virtude nasce da boa educação, esta das boas leis que, por sua vez, se originam dos tumultos. Nas palavras de Berns (2000, p. 117): “[...] os tumultos não engendrariam boas leis se eles mesmos já não estivessem marcados pela virtude que dispensa estas leis. A desordem permite a ordem na medida em que a ordem já sempre antecede à desordem, mas sem impedi-la uma vez que somente a desordem permite pensar o nascimento da ordem".

É, pois, graças à circularidade que a lei, ao mesmo tempo em que nasce dos conflitos, os mantém sob controle. Dessa maneira, eles permanecem férteis, dotados daquela virtude que faz com que as inimizades nascidas do conflito produzam necessidade e não ambição. É a isso que Maquiavel chama a atenção, em Discursos (I,37): “[...] sempre que os homens não precisam combater por necessidade, combatem por ambição". Enquanto os desejos são "[...] coagidos pela necessidade", as inimizades permanecem sãs e culminam em leis justas como, por exemplo, a da criação dos tribunos. Quando, porém, se "[...] começa a combater por ambição", prevalece o uso de meios privados no interesse de uma só pessoa, família ou facção, cujo resultado final é a destruição da república. Como o desejo é, por definição, desmedido e a ambição

${ }^{7}$ Como mostraremos adiante, a manutenção pelas leis de um estado de necessidade em condições de impedir a ambição de reinar tem uma força limitada. Por isso, a exigência levantada por Maquiavel de retornar periodicamente às origens, isto é, de voltar à experiência mesma que deu origem à lei para devolver-lhe o vigor inicial. 
só tem lugar quando a necessidade cessa, a única possibilidade de impedir a primeira de nascer parece ser cultivar a segunda pelas leis e instituições ${ }^{7}$.

Graças à sua tese dos conflitos, Maquiavel pode definir o motor da dinâmica da lei, uma dinâmica oposta à ideia de um bom primeiro legislador e ao qual Roma deveria creditar suas boas instituições. A tese da vitalidade dos conflitos é elaborada, com efeito, nos primeiros capítulos dos Discursos, fundamentalmente com a ajuda de uma comparação extraída da história romana, com os exemplos espartano e veneziano, culminando na rejeição da tese grega do bom primeiro legislador. Vamos resumir brevemente o argumento maquiaveliano.

\section{Lei e violência originária}

Maquiavel divide os Estados conforme o modo de sua fundação. Primeiramente, distingue-os segundo a origem: alguns são desde o início livres (quando fundados por autóctones); outros estão submetidos (quando fundados por estrangeiros). Introduz, em seguida, uma nova distinção em função do valor de sua constituição originária. Assim, alguns “[...] receberam leis, na sua origem ou depois de não muito tempo, de um só homem e de uma só vez [...]; outros as receberam ao acaso e em várias vezes, segundo os acontecimentos" (Discursos I,2). Exemplos dos primeiros são Esparta e Veneza; dos últimos, é Roma.

Se, portanto, a origem da legislação de Roma é distinta daquela de Esparta, que a recebeu "[...] de uma só vez [...] sem precisar corrigi-la" (Discursos I,2), também não se assemelha ao extremo oposto ilustrado por aquela cidade cujas "[...] ordenações estão de todo fora do caminho reto (diritto cammino) que a possa conduzir ao fim perfeito e verdadeiro" (Discursos I,2). Para "[...] as que se encontram neste grau é quase impossível reordenar-se" (Discursos I,2). Cidades como Roma, ainda que não tenham uma "[...] ordenação perfeita, tomaram um princípio bom (principio buono) capaz de tornar-se melhor e podem vir a tornar-se perfeitas através do curso dos acontecimentos" (Discursos I,2). Para Maquiavel, esse "princípio bom", que desde a origem assegura a perfectibilidade de uma república, ainda que não a faça perfeita desde o início, é o vivere libero. Trata-se de repúblicas que "[...] tiveram o seu princípio livre" em oposição àquelas "que desde o início tiveram seu princípio na servidão" (Discursos I,49).

A vantagem do modelo espartano, que conta com uma constituição perfeita desde as origens, é a garantia da estabilidade e duração, pois este está protegido do risco da corrupção e dos conflitos que poderiam levar à luta civil. Maquiavel parece sacrificar essas duas determinações essenciais 
do modelo espartano, estabilidade e duração, em favor de uma determinação ainda mais essencial: a liberdade, sobretudo a capacidade de ampliar sua liberdade externa e interna, sempre que a necessidade a induzir a isso. A estabilidade do modelo espartano pode muito bem converter-se num impedimento para a expansão, com consequente sacrifício do conflito a favor de uma concórdia forçada.

A afirmação da liberdade como princípio essencial do modelo republicano concebido por Maquiavel, longe de excluir a igualdade, a pressupõe: "[...] que se constitua, portanto, uma república onde existe ou se criou uma grande igualdade $^{8}$ e, ao contrário, que se ordene um principado onde existe grande desigualdade, caso contrário se fará algo sem equilíbrio e de vida curta" (Discursos I,55). Essa assimilação do princípio da igualdade ao fundamento da ordem republicana, como sua prévia condição de possibilidade, estabelece uma intrínseca correspondência com o princípio e objetivo de liberdade. Enquanto a liberdade é princípio constitucional da república, mas também conteúdo e objetivo do desenvolvimento republicano, a igualdade é sua condição de possibilidade: sem ela, não é possível fundar uma república. Mais radicalmente ainda, Maquiavel afirma que a aristocracia feudal não somente impede o nascimento de um regime republicano, mas impossibilita qualquer tipo de organização estatal que não seja tyrannica: ao contrário da vita libera republicana, aquela representa a corrupção, a destruição das ordini e da vita civile $^{9}$. Numa palavra: desigualdade identifica-se com a ausência de vivere político $^{10}$ pura e simplesmente.

Assim, uma vez que a primeira constituição romana não foi imposta de fora por um sábio legislador, a história ganha toda sua importância, porque sua legislação é elaborada "[...] no curso dos acontecimentos". Trata-se, portanto, de compreender como uma origem tão modesta, tão afastada da perfeição, foi possível sem se afastar do diritto cammino (Discursos I,2). Se, pois, não se pode atribuir a Rômulo a glória de haver dotado Roma desde as

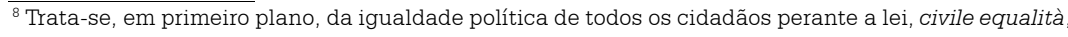
como Maquiavel já afirmara, em Discursos I,2, que não exclui a existência de dois humores diferentes, do povo e dos grandes, os quais se contrapõem, como plebe e nobres, na antiga república romana, num quadro institucional. Contudo, a exigência da supressão ou ausência da aristocracia feudal (constituída de gentis-homens e senhores), para a fundação de uma república, leva a pressupor de que se trata também de uma igualdade social (di sustanze) e não tão somente política (di grado).

${ }^{9}$ Como podemos identificar nesta passagem: devido à desigualdade "[...] nessas províncias [Nápoles, Roma, Romanha e Lombardia] jamais surgiu nenhuma república, nem qualquer vivere político" (Discursos I,55).

${ }^{10}$ Ercole faz uma distinção clara entre vivere civile e vivere político: " $[. .$.$] se vivere civile ou pubblico é$ em Maquiavel normalmente expressão genérica para indicar o vivere em Estado, seja na forma republicana ou monárquica, vivere politico é, pelo contrário, em geral expressão específica para indicar justamente o Estado livre ou bem ordenado no sentido pleno e completo, ou seja, no sentido republicano" (ERCOLE, 1917, p. 168).
} 
origens de uma sábia legislação - ao contrário do que fez Licurgo, em Esparta -, pelo que se pode louvá-lo? Em outras palavras, que importância têm os atos fundadores e constitutivos de Rômulo, para a elaboração da perfeição da constituição romana?

A questão requer, primeiramente, uma análise do valor que Maquiavel atribui a esse momento originário em relação à evolução futura de Roma e da concepção maquiaveliana de lei em geral. Em um segundo momento, será preciso ilustrar a centralidade do momento originário, mostrando o papel que ele desempenha, após as instituições já estabelecidas, para impedir a corrupção.

\section{Lei e violência originária}

A importância do momento originário pode ser captada pela análise de Discursos I,9: Maquiavel evidencia ali a ruptura radical em relação ao julgamento fixado pela tradição quanto ao fratricídio romuloeano ${ }^{11}$. Com efeito, a tradição, seja cristã, seja pagã, centra-se na relação meio-fim: ou condena o fratricídio como injustificável, independente do fim proporcionado; ou justifica a morte violenta de Remo por Rômulo, em nome da grandeza do resultado (a fundação de Roma). Maquiavel, opondo-se a essas interpretações, afasta-se de qualquer visão moral ou de uma visão providencialista da história e reconhece no homicídio o ato fundador enquanto tal, único capaz de fazer emergir sujeitos políticos. Acompanhemos o raciocínio de Maquiavel

O começo da resposta à relação entre a violência de Rômulo e à constituição de Roma é enunciado por um princípio que Maquiavel denomina "regra geral": "E deve-se tomar isto por uma regra geral: que nunca, ou raramente, ocorre que alguma república ou reino seja desde seu princípio bem ordenado ou reformado inteiramente com ordenações diferentes das antigas, se não é ordenado por uma só pessoa" (Discursos I,9). O motivo dessa exigência se se deve ao fato de que "[...] a multidão não é capaz de ordenar uma coisa, porque não conhece o bem que há nela devido às diferentes opiniões que têm entre si" (Discursos I,9). O poder, ou ato fundador de uma ordem enquanto

\footnotetext{
${ }^{11}$ Thomas Berns (2000, p. 43-70) elabora uma breve história do fratricídio romuloeano, antes de Maquiavel. Ele resume as conclusões dessa história em quatro posições distintas: "1) a condenação moral (Cícero, Horácio, a teologia medieval, Du Bellay) que pressupõe a idéia de um primeiro 'pecado' que determina a história futura ou a visão providencial cristã; 2) a posição 'oficial' (Lívio, Ovídio, Dionísio de Alicarnaso) que compartilha a condenação moral, mas defende Rômulo ocultando seu homicídio; 3) a admissão pouco explícita do fratricídio, justificado como ocorrida em nome da futura grandeza de Roma, tanto da parte pagã (Virgílio, Propércio, Túlio) quanto da parte cristã (Agostinho, Dante, Petrarca: novamente, portanto, uma leitura providencial da história); 4) o reconhecimento do fratricídio, para além de qualquer forma de providencialismo, do caráter de necessidade estritamente política (Ênio, Floro, Petrarca que retoma este último)" (BERNS, 2001, p. 16-17; BERNS, 2000, p. 67-70).
} 
absoluta, não pode ser compartilhado. Não há ação política mais eficaz do que aquela que condensa, numa só vontade, a vontade e o poder de muitos. Não resta dúvida de que, se esse postulado é necessário para fundar uma nova ordem, perde legitimidade quando se trata de conservá-la e governá-la, já que neste caso se requer a participação de uma vontade mais ampla: “[...] ainda que um só seja mais capaz de ordenar, a coisa ordenada não durará muito se repousar sobre os ombros de um só, mas apenas quando for entregue aos cuidados de muitos, e a muitos couber mantê-la" (Discursos I,9) ${ }^{12}$.

Uma vez que é preciso recorrer a procedimentos extraordinários para fundar novas ordens institucionais, é necessário eliminar todas as forças hostis ou potenciais inimigas de tais ordens e instituições, mais precisamente das novas forças e poderes que estas mesmas ordens instituem. A vitimação de Remo representa um sacrifício fundador de extraordinária significação atribuindo à origem de uma instituição ou de uma ordem política um caráter sagrado e inviolável, como se a morte que inaugura tais instituições simbolizasse a pena que acarreta sua transgressão. De outro lado, essa prova violenta de um extraordinário e absoluto poder marca a transformação do poder pessoal em institucional: a transição do poder e autoridade de "um só" homem para o poder daquilo que somente "muitos" poderão conservar. Enquanto o poder e a inteligência política do fundador de ordens e instituições não são aptos para mantê-los e governá-los, a gestão de muitos - nunca capaz de fundar e ordenar - é a única em condições de manter e consolidar as instituições.

Nessa ideia parecem cifrar-se distintas chaves interpretativas: a transição da monarquia à república; a passagem do poder pessoal ao institucional; mas, sobretudo, o isolamento do governante, que é a solidão do poder na tomada de decisões e em sua atuação política, sempre só e único responsável por seus atos. A solidão do governante não é, porém, um convite ao poder arbitrário e absoluto. Pelo contrário, o político pode, ou deve, isolar-se no poder somente a partir do momento em que "[...] tenha a intenção de querer favorecer não a si mesmo, mas o bem comum, não a sua própria descendência, mas a pátria comum" (Discursos I,9). Consequentemente, no exemplo do fratricídio cometido por Rômulo, é necessário que "[...] se considere o fim que o levou a cometer o homicídio" (Discursos I,9), ou compreender que Rômulo foi violento "[...] para reconciliar (racconciare) e não para destruir (guastare)", como o demonstra o fato de haver "[...] ordenado um Senado para servir-lhe de conselho" (Discursos I,9). Esse modo de colocar as coisas parece, à primeira vista, perfeitamente coerente com a convicção sustentada pelo maquiavelismo, e poderia ser resumida na frase seguinte: "Convém que, se o fato o acusa, o

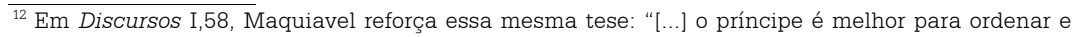
renovar as ordens, o povo é melhor para manter o ordenado". 
efeito o escusa" (Conviene bene, che, accusandolo il fatto, lo effetto lo scusiDiscursos I,9). É preciso, para bem compreender Maquiavel, ir além da simplificação operada pelo maquiavelismo, que pretende ler aqui unicamente a justificação dos meios pelo fim.

Primeiramente, é necessário notar que o fato de, na origem de toda instituição e de toda ordem, existir um crime (ou uma violência, ou um exercício de poder "extraordinário", do tipo que for), significa que toda instituição e ordem transcendem sempre a violência que as funda, ao mesmo tempo em que representam a superação e a supressão de todas as violências anteriores, pré-institucionais. Não há, desde o Estado, instituições nem ordenamentos ou leis que não se fundem e se estabeleçam sem um grau de maior ou menor violência, proporcional à violência que visam a suprimir. Isso significa que as ordens e instituições representam sempre a abolição da violência fundadora, a qual foi necessária para eliminar e deixar à margem dela, "fora da lei", toda outra possível violência; em outras palavras, toda lei, ordem e instituição significa que, fora delas, tudo é crime. Por isso, uma desordem institucional somente se resolve a partir de um reordenamento ou refundação institucional, recorrendo ao mesmo poder absoluto e à mesma violência originária que constituíram em seu princípio essas ordens e instituições.

Em segundo lugar, é preciso perguntar-se: no ato da fundação, o que se sabe? Considerando que toda ação política é marcada pela opacidade, que resiste à previsão e está destituída de garantias quanto ao resultado, como este poderia legitimar a ação? Berns aponta com muita pertinência o foco da questão: o fim que justifica os meios chega sempre muito tarde, pois

[...] não pode tratar-se de "Rômulo tem o direito de...", mas somente de "Rômulo tinha o direito de...". A justificação só pode dar-se no futuro, o que vale dizer que não pode ser expressa, ao menos não como "direito"; que ninguém pode dizer de Rômulo que ele poderia fazer o que fez, não porque se trata de um homicídio, mas porque "em nome de que"? (BERNS, 2000, p. 140).

Consequentemente, o efeito não escusa sempre e, especialmente, não desculpa no momento em que a ação é praticada. A indeterminação que cerca o efeito torna isso difícil, pois jamais a justificação é adquirida previamente, no instante em que a ação se desenrola. Isso desfaz o discurso do maquiavelismo segundo o qual o fim - determinado (ou conhecido) exclusivamente pelo agente - parece sempre escusar os meios. É preciso, nesse sentido, integrar a relação meio e fim à temporalidade. Assim, mais do que a submissão de um meio a um fim, será possível examinar a 
"conveniência" que pode existir entre a violência representada pelo fratricídio e a instituição da ordem legal constituída pela fundação de Roma.

Servindo-nos mais uma vez do estudo de Thomas Berns (1997, p. 39), podemos resumir essa relação nos termos seguintes:

\begin{abstract}
Indeterminação das boas leis primeiramente, por causa de sua relação necessariamente circular com a história; indeterminação a fortiori de seu momento originário que se determina unicamente como momento que faz vir junto um futuro sempre indeterminado que escusa um necessário engajamento presente que somente pode acusar na medida em que faz violência à história. Eis o que exprime a famosa frase já diversas vezes citada: "conviene bene che, accusandolo il fato, lo effetto lo scusi". A conveniência (conviene, cum venire, vir junto) que deve haver entre o que não é ainda legal e o que o será.
\end{abstract}

O que, portanto, Maquiavel nos ensina, explica Berns, é que as leis se definem unicamente em sua relação circular com a história. É essa circularidade que torna necessário o papel do fundador virtuoso. A lei não pode deixar de ser produto da história, mas, ao mesmo tempo, jamais pode sê-lo suficientemente. Assim, para impor a lei, apesar das relações circulares desta com a história, é imprescindível o momento da violência. Contudo, esse momento fundador jamais está à altura das questões que coloca, uma vez que a resposta a essa exigência crucial se exprime ou por uma remissão ao futuro - o efeito ou fim -, isto é, a um apelo à legalidade instaurada, ou então a uma pura sucessão histórica, na qual a lei não é mais do que o resultado possível de um ato violento, sinal de sua imposição ao fluxo da história. Enfim, na política, nada está assegurado definitivamente, no momento em que a ação se desenrola e, por isso, somente o tempo poderá dizer da verdade, ou conveniência, dos meios empregados.

Retorno à origem e combate à corrupção

Pensamos que essas considerações elucidam suficientemente a primeira das duas questões propostas anteriormente: a da importância do momento originário romuloeano. Cabe-nos, agora, examinar a segunda questão proposta: a centralidade do momento originário e seu papel, depois que a lei e as instituições estão instauradas.

A lei, devido à sua relação circular com a história, permanece sempre exposta à possibilidade da corrupção. Maquiavel deixa clara essa ideia em mais de um lugar. Assim, por exemplo, distingue os conflitos construtivos 
dos destrutivos. Os primeiros deram origem às boas instituições romanas (Discursos I,2-4). Os últimos são causa da luta das facções em Florença, que resultaram em sangue e exílio (Discursos III,1; História de Florença VII,1); ou, então, os conflitos motivados pela lei agrária em Roma, que culminaram na guerra civil responsável pelo fim da liberdade romana (Discursos I,37). Essa distinção aponta para o fato de que jamais dispomos de uma garantia, de um critério determinado, para evitar a degeneração dos bons conflitos em maus, mas, pelo contrário, que os primeiros sempre podem levar aos últimos.

As leis encontram, como podemos notar, um limite intransponível na corrupção política da sociedade e de suas instituições: "[...] não há leis nem ordens que bastem para frear a corrupção generalizada" (Discursos I,18). Quando o tecido social (a "matéria" de que é constituída a coletividade política) e as instituições políticas (as ordini) se corrompem, não há condições para a produção da legalidade. A lei deixa de gerar e reproduzir vínculos; em lugar de ampliar e reforçar o público, debilita-o e o submete ao privado. É o que Maquiavel denomina "corrupção": não é um processo moral e nem mesmo econômico, mas estritamente político de perda do sentido de bem comum. Embora não seja possível encontrar um conceito de "corrupção", na obra maquiaveliana, esta poderia perfeitamente ser definida, sustenta SanchezParga (2005, p. 488), como "[...] a submissão do público ao privado, a perversão dos interesses coletivos pelos particulares; [...] a apropriação privada do público com a conseqüente despolitização do público e privatização da política".

Como fenômeno estritamente político, o sujeito do processo de corrupção não corresponde a indivíduos, mas a entes coletivos: a cidade ou república, mas também as instituições (ordini), as leis e os cidadãos enquanto corpo político. Em suma, "forma" e "matéria", aparato institucional e corpo coletivo dos cidadãos, estes são os sujeitos da corrupção. Maquiavel estabelece, porém, a prioridade política da corrupção institucional sobre a corrupção do corpo cidadão: "[...] um mau cidadão não pode agir mal numa república que não

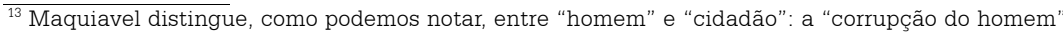
(sua propensão à maldade) não é um problema que merece da parte dele grande atenção, e sim a "corrupção do cidadão" (a "matéria" da qual é constituída a cidade). Interessa-lhe a última, não a primeira. Está preocupado com o "bom cidadão" e não com o "homem bom"; isto é, não se interessa pelo aperfeiçoamento moral do indivíduo, mas pelo cultivo das virtudes cidadãs. Quais são estas? Ajudados pelo estudo de Pinzani (2006, p. 88-89), podemos organizá-las num conjunto de quatro qualidades fundamentais: 1) a subordinação do bem particular ao bem comum: a virtude cívica desenvolve nos homens a capacidade de servir a pátria até com a própria vida, se necessário; 2) a coragem: o cidadão dotado de virtude cívica não teme defender a cidade ou expandir seus domínios, sempre que isso se mostra necessário para conservá-la livre; 3) a religiosidade: o bom cidadão é temente a Deus, o que faz com que respeite os preceitos legais como se fossem mandamentos divinos; 4) a repugna ao ócio: o ideal de homem está vinculado à vida ativa e produtiva e não à contemplação e meditação, como era para o pensamento medieval-cristão.
} 
seja corrupta" (Discursos III,8). Não é possível existir cidadãos corruptos em instituições incorruptas. É porque as instituições se corrompem que é possível existir cidadãos corruptos. ${ }^{13}$ Os homens não são mais ou menos corruptos numa época do que em outra, e sim a corrupção das leis e instituições de cada Cidade é maior ou menor, segundo as circunstâncias históricas concretas.

A questão que isso levanta é a seguinte: se as instituições impedem que os cidadãos se corrompam, e se estes nada podem contra instituições incorruptas, por que e como se corrompem as instituições? Maquiavel destaca alguns fatores. Em primeiro lugar, é preciso considerar a própria ação do tempo, que desgasta a importância das instituições e leis, ao naturalizá-las. Um segundo fator é o "descompasso" entre leis e instituições. As "leis" (leggi), explica Maquiavel, variaram, no exemplo romano em questão (Discorsi I,18), de acordo com os "acontecimentos" (accidenti) da história. Contudo, enquanto as leis "variaram", adaptando-se ao novo conteúdo político e social da cidade, as "instituições" (ordini) permaneceram inalteradas. Desse modo, ocorreu um descompasso ${ }^{14}$ entre essas disposições institucionais fundamentais e as leis (entre ordini e leggi). Esse descompasso acentuou-se com o tempo, fazendo com que as primeiras, uma vez tornadas más, isto é, inapropriadas à situação, acabassem corrompendo as últimas, por mais adequadas que tenham sido aos problemas do momento, tornando-as totalmente ineficazes, por se revelarem incapazes de resistir à corrupção crescente dos costumes. Esse processo observado na história romana leva Maquiavel a formular a regra geral: "[...] se as leis mudam (variano) numa Cidade segundo os acontecimentos (accidenti), as instituições (ordini) não mudam nunca, ou raramente, donde resulta que as novas leis não bastam, porque as instituições, que permaneceram imutáveis, as corrompem" (Discorsi, I,18). Consequentemente, para que seja reconstituído o equilíbrio da relação, é necessário poder modificar não somente as leis, mas também as instituições ${ }^{15}$.

A corrupção é, acima de tudo, um problema político e não pessoal e muito menos moral. Por isso, a necessidade de politizar os meios para a solução. Isso supõe radicalizar a questão em termos extremos: é possível eliminar totalmente a corrupção, numa república corrompida, sem liquidar ao mesmo tempo o ordenamento republicano? A resposta é, evidentemente, negativa. Para não ter de sustentar explicitamente a necessidade de destruir a ordem política republicana, a fim de extirpar a corrupção, recorre a um enunciado mais positivo: se a corrupção consiste em destruir o público, não há outro modo de eliminá-la senão refundando o político em suas origens e princípios. Esse caminho é defendido por Maquiavel, em Discursos III,1: um Estado

\footnotetext{
${ }^{14}$ Um "antagonismo cronológico", nas palavras de Gennaro Sasso (1967, p. 115).

${ }^{15} \mathrm{Ou}$, como diz Sasso (1967, p. 115): “[...] não só o elemento relativamente 'dinâmico', mas também o elemento relativamente 'estático' da ordem estabelecida".
} 
mantém sua autoridade somente por meio de um retorno contínuo ao momento da origem. Significa dizer: àquele momento da violência romuloeana, e esse retorno repõe a lei na indeterminação originária que, por sua vez, a recoloca em movimento. O próprio título do capítulo citado já anuncia tal procedimento: "Quem quiser que uma seita ou uma república viva por muito tempo, precisará fazê-la retornar freqüentemente ao seu princípio". Em consequência dessa "regra geral", como a define Maquiavel, as repúblicas "melhor ordenadas e que têm vida mais longa, são aquelas que, mediante suas próprias ordenações, podem renovar-se freqüentemente" (Discursos III,1).

Em que consiste esse "retorno ao princípio"? Maquiavel faz diferentes alusões ao longo do capítulo: pode-se tratar de um modo de fazer com que os Estados "[...] retomem seu prestígio (riputazione) e vigor (augmento) iniciais"; ou pode ser algo que propicia a ocasião para que "[...] os homens que convivem em qualquer ordenação se examinem (si riconoschino) freqüentemente"; finalmente, pode ser uma maneira de "[...] trazer à memória a punição e renovar em seus espíritos o medo". Esta última função, que parece ser decisiva, é ilustrada pelo exemplo do Estado florentino:

Diziam a propósito disso os homens que governaram o estado de Florença de 1434 até 1494, que seria necessário retomar o estado a cada cinco anos, caso contrário seria difícil mantê-lo. Por retomar o estado entendiam disseminar entre os homens o terror e o medo que haviam disseminado ao tomá-lo, quando abateram todos os que, segundo aquele modo de viver, haviam se conduzido mal. (Discursos III,1).

O que é capaz de provocar esse retorno ao princípio? Maquiavel sugere três caminhos distintos. Um é extrínseco: os perigos aos quais o Estado está sujeito face à ameaça externa. No caso de Roma, a invasão francesa, que permitiu a Roma "[...] renascer e, renascendo, ganhar nova vida e nova virtù; e também retomar a observância da religião e da justiça" (Discursos III,1). Dois outros são intrínsecos: "[...] ou provêm de alguma lei que muitas vezes reveja a conduta dos homens que pertencem àquele corpo, ou de algum homem bom que surja entre eles e que, com seus exemplos e suas obras virtuosas, produza o mesmo efeito de uma ordenação" (Discursos III,1).

Bruto é apontado como exemplo do segundo caminho: pelo sacrifício à morte dos filhos, cuja "[...] severidade foi tão necessária quanto útil para manter em Roma a liberdade" (Discursos III,3), provoca um retorno à origem, mostrando que a ordem da lei não é natural, que ela não é "familiar", que ela jamais está instaurada para sempre, pois o risco da corrupção a espreita sempre. O exemplar nas ações de Bruto, segundo Maquiavel, não são as 
reformas que introduz, e sim o fato de remeterem à afirmação da nãonaturalidade da lei, na medida em que submete seus próprios filhos a ela, ao condená-los à morte.

A segunda via intrínseca de fazer o Estado retornar às origens consiste nas leis e instituições. Para Maquiavel, esse caminho é o menos aleatório, de forma que "[...] são melhor ordenadas e têm vida mais longa aquelas [repúblicas] que, mediante suas ordenações, podem renovar-se periodicamente" (Discursos III,1). Maquiavel cita como exemplos de instituições que possibilitaram a Roma o retorno ao princípio "[...] os tribunos da plebe, os censores e todas as outras leis contra a ambição e a insolência dos homens" (Discursos III,1). No entanto, essas instituições não provocam por si mesmas um processo de retorno à origem, mas "[...] precisam ganhar vida graças à virtù de um cidadão que, corajosamente, faça tudo para pô-las em prática, contrariando o poder daqueles que as transgridem" (Discursos III,1). Maquiavel refere também a atividade parlamentar francesa como uma via intrínseca de retorno à origem, "[...] sempre que executa algo contra um príncipe do reino e quando condena o rei em suas sentenças" (Discursos III,1). Quer dizer, ao controlar a ambição da nobreza e do rei, o Parlamento produz o retorno ao princípio, pelo fato de reafirmar a autoridade originária da lei, que fica perdida quando se naturaliza.

Mostra-se nesta última via de retorno ao princípio a dupla função cumprida pela lei: por um lado, aquilo a que se deve retornar corresponde à origem romuloeana do Estado (isto é, a volta à violência pré-institucional e fundadora da lei) e, por outro, aquilo que deve provocar esse retorno corresponde à lei propriamente dita, instituída numa ordem política já fundada. As "boas leis" às quais Maquiavel alude são precisamente aquelas que estão dotadas da capacidade de provocar esse retorno à origem do Estado.

O que existe no princípio dos Estados que possui tal força renovadora? Em que consiste essa "bondade", a qual menciona Maquiavel, que está na origem e que é capaz de devolver "[...] o prestígio e o vigor iniciais" (Discursos III,1) aos Estados? Não pode ser a rememoração do conteúdo constitucional, nem a fixação numa origem idealizada, pois isso seria recusar a mudança que, precisamente, é o que determina as boas leis as quais requerem, para sua conservação, o retorno às origens. A origem a que é preciso retornar periodicamente é, de certa forma, anterior a qualquer conteúdo. É o momento constitutivo enquanto tal que deve ser revivido; não o "modo de viver" anterior à instituição do Estado, mas a experiência vivida na sua gênese: a virtude, certamente, mas, sobretudo, o "medo" (paura), o "terror" (terrore) e a "punição" (pena). Não se trata, pois, de uma volta a um momento determinado do passado, mas a uma experiência originária que deve repetir-se periodicamente. 
O que a origem romuloeana acrescenta à lei, quando esta retorna àquela? Certamente, não seu conteúdo, derivado do fato enquanto tal (o fratricídio cometido por Rômulo), já que isso tiraria da lei qualquer possibilidade de generalidade e impediria toda escusa do homicídio. Em outras palavras, suprimiria a indeterminação da lei e de sua origem. O que importa na origem romuloeana é aquilo a que se retorna: a revivência da experiência do "medo", do "terror" e da "punição" do acontecimento originário da fundação, que não suprime a generalidade da lei. A lei, pelo contrário, no decurso do tempo, nos faz acreditar na sua naturalidade, na sua legitimidade definitiva, como se um bom regime, protegido do perigo da corrupção, pudesse ser estabelecido definitivamente. A revivência do acontecimento originário a que é preciso retornar nos aponta para a dificuldade da instauração de semelhante regime.

\section{Considerações finais}

A violência fundadora da ordem política não é estranha à violência que funda a lei, no sentido de que ambas (violência fundadora e violência da lei) se constituem para abolir a violência originária, que existe previamente (não no sentido de anterioridade temporal e, sim, lógica), isto é, à margem de todo ordenamento político-legal. Por isso, a necessidade de um mito ou crime fundador para simbolizar e justificar a passagem de uma violência "prévia" tão destruidora que é preciso destruí-la: a violência construtora e ordenada da existência política e legal, quer dizer, o crime fratricida de Rômulo (Discursos I,9). A violência fundadora do Estado e da ordem política é exatamente a mesma violência fundadora da lei, no sentido de que tanto o Estado quanto a lei se constituem para abolir a violência originária que existe "antes" ou "à margem" de todo ordenamento estatal, político e legal da sociedade; em outras palavras, fora do Estado, da política e da lei não existe mais do que violência.

Em conclusão, podemos afirmar que Maquiavel recusa qualquer forma de determinação definitiva e definitivamente garantida da lei. Essa recusa se exprime por sua preferência pelo "caminho reto" romano, em vez do caminho espartano, da doação da legislação definitiva por Licurgo; isto é, pela determinação histórica da lei como resultado do conflito. Essa relação circular da lei com a história torna a lei potencialmente corrompida, o que exige o contínuo retorno à origem. Em suma, quando a lei deixa de estar submetida às vicissitudes da história, ao conflito insolúvel que marca as sociedades humanas, ela se cristaliza. Tal "naturalização" da lei a corrompe, pois a impede de acompanhar o movimento contínuo da história. O único modo de devolver-lhe o vigor inicial é pela revivência do acontecimento 
originário de medo e terror do ato fundacional. Assim, ainda que a lei seja a superação da violência, não pode separar-se definitivamente desta, sem perder a eficácia e a capacidade de regular o conflito.

AMES, J. L. Law and violence or legitimizing politics in Machiavelli.Trans/Form/Ação, (Marília); v.34, n.1, 2011, p.21-42.

ABSTRACT: One of the Machiavelli's most famous and innovative thesis states that good laws arise from social conflicts, according to the Roman Empire example of the opposition between plebs and nobles. Conflicts are able to bring about order in virtue of the characteristic constrictive force of necessity, which prevents the ambition to prevail. Nonetheless, law does not neutralize the conflict just give it a regulation. So, law is subjected to history, to the continuous change, which means that it is potentially corruptible. On this account, Machiavelli says that a State can only maintain its authority through a continuous return to the originary moment, viz. to the revival of the experiences of "fear", "terror" and "punishment" lived in the originary event of the foundation. For that reason, in the origin of law is also the violence, whose combined function is to provide legitimacy to its exercise by the State apparatus as the only form to preserve political life from ruin.

KEYWORDS: Machiavelli. Law. Violence. Conflict. Politics. State.

\section{Referências}

BERNS, Thomas. L'antimachiavélisme de Machiavel ou l'indétermination assumée de la loi. In: DIERKENS, A. (Ed.). L'antimachiavélisme de la renaissance aux lumières. Bruxelles: Editions de l'Université libre de Bruxelles, 1997. v. 8.

BERNS, Thomas. Violence de la loi à la renaissance: l'originaire du politique chez Machiavel et Montaigne. Paris: Éditions Kimé, 2000.

BERNS, Thomas. Il 'Romolo machiavelliano'. Il momento dell'origine dello stato nel pensiero di Machiavelli. In: CASTELLI, Patrizia (Éd.). Finestre sul rinascimento. Ferrara: Università degli Studi di Ferrara, 2001. p. 3-30.

BIGNOTTO, Newton. Maquiavel republicano. São Paulo: Loyola, 1991.

ERCOLE, Francesco. Lo 'Stato' nel pensiero di N. Machiavelli. Studi I: Lo stato bene ordinato o libero. Palermo: Tip. Industriale, 1917.

GUICCIARDINI, Francesco. Considerazioni intorno ai Discorsi del Machiavelli sopra la Prima Deca di Tito Livio. In: GUICCIARDINI, Francesco. Opere. Bari: Palmarocchi, 1933. v. 8.

LEFORT, Claude. Desafios da escrita política. São Paulo: Discurso Editorial, 1999.

MACHIAVELLI, Niccolò. Istorie fiorentini. In: MACHIAVELLI, Niccolò. Opere di Niccolò Machiavelli. Torino: UTET, 1986. v. 2. 
MACHIAVELLI, Niccolò. Discorsi sopra la prima Deca di Tito Livio. In: MACHIAVELLI, Niccolò. Opere di Niccolò Machiavelli. Torino: UTET, 1999. v. 1.

PINZANI, Alessandro. Guirlande di fiori e catene di ferro: istituzioni e virtù politiche in Machiavelli, Hobbes, Rousseau e Kant. Firenze: Le Lettere, 2006.

SANCHEZ-PARGA, José. Poder y politica en Maquiavelo. Rosario: Homo Sapiens Ediciones, 2005.

SASSO, Gennaro. Studi su Machiavelli. Napoles: Morano, 1967.

SASSO, Gennaro. Niccolò Machiavelli: storia del suo pensiero politico. Bologna: Il Mulino, 1980.

SKINNER, Quentin. Liberty befor liberalism. Cambridge: Cambridge U.P., 1998. 
